\title{
Influence of Drying Methods on the Drying Characteristics and Nutritional Quality of Fermented Locust Beans
}

\author{
Olalusi A.P. ${ }^{1}$, Omosebi M.O. ${ }^{2}$ and Agbola O.Y. ${ }^{1}$
}

\author{
${ }^{1}$ Department of Agricultural and Environmental Engineering, Federal University of Technology, Akure, Ondo State, Nigeria. \\ ${ }^{2}$ Department of Food Science and Technology, Mountain Top University, Ogun State, Nigeria. \\ Corresponding Author: apolalusi@futa.edu.ng and moomosebi@mtu.edu.ng
}

\begin{abstract}
This study was designed to give the drying characteristics of fermented locust beans using different drying methods. The production of good quality of fermented locust beans is essential, having known its rate of spoilage. Different methods have been used over time and this has probably affected the quality of stored fermented locust beans. This study is meant to guide the producer in selecting the best drying method to be used for processing of fermented locust bean. Three different drying methods were used: the mechanical (convective) dryer, indirect (cabinet) solar dryer and sun drying. The mechanical (convective) drying experiments were conducted for four air drying air temperatures at $45^{\circ} \mathrm{C}, 55^{\circ} \mathrm{C}, 65^{\circ} \mathrm{C}$ and $75^{\circ} \mathrm{C}$ at air velocity of $0.9 \mathrm{~m} / \mathrm{s}$. During the drying process, the weight loss was measured at 30 min intervals for all the drying methods. The result was used to determine the moisture content, moisture ratio and the drying rate. The lowest moisture content was at the mechanical drying $\left(75^{\circ} \mathrm{C}\right)$ due to the high air temperature than the other drying methods. The constant rate and the falling rate were observed at the early hours of the drying for the mechanical drying method. The drying rate also varies with the drying methods. The mechanical drying at air temperature of $55^{\circ} \mathrm{C}$ at air velocity of 0.9 $\mathrm{m} / \mathrm{s}$ of the fermented locust beans gives the best quality.
\end{abstract}

Keywords—Locust bean, Nutritional Value, Moisture content, Drying characteristics.

\section{INTRODUCTION}

The African locust bean, Parkia biglobosa, is an important tree crop in Africa. The tree is a perennial one and its life cycle is for many years. It is grouped under the leguminous crops family called the leguminosae, now called fabaceae, and further under the sub-family mimosoideae. It is a natural nutritious condiment which is common in the traditional diet of both rural and urban dwellers in West-African countries including Nigeria. Locust bean seed is the matured fruit seed that comes from the parkia tree. It is harvested and processed into a fermented product. Parkia biglobosa seeds serve as a source of useful ingredients for consumption. It has been reported that the husks and pods are used for feeding livestock, and the floury pulp can be used as a refreshing drink, which is rich in vitamin $\mathrm{C}$ and sugar. Apart from its excellent caloric and nutrient value, its wide adaptability, drought resistance, and multifunctional usage makes it a sustainable source of its by-products. It is a multipurpose tree of which most parts are useful.

The most important part of the tree is found in its seeds which are processed into food condiment. Apart from the flavouring attribute of the processed locust bean, it also contributes significantly to the intake of protein, carbohydrate, calcium, phosphate, iron content and essential fatty acids $[1,2,3,4,5]$. The seed has high protein content $(40 \%)$, high vitamin, moderate fat content $(35 \%)$, carbohydrate and macronutrients such as potassium, sodium, magnesium, calcium, nitrogen and phosphorus [6]. The processing of locust bean into food condiment is mainly done manually which makes it tedious for large scale production. The daily demand for this condiment is on the rise because of its nutritive and medicinal benefits. The raw African Locust beans are nutritionally deficient but when fermented into food condiment, Iru, the physical, chemical and nutritional characteristics of the seeds improves [7]. Fermentation improves the digestibility of many foods, increases nutritional values, and provides important living enzymes and beneficial microorganisms to our diet. There is a breakdown of certain constituents, reduction of anti-nutritional factors in grains and the synthesis of B-vitamins [8].

Drying is a method of food preservation which removes moisture from the food to avoid the growth of bacteria, yeasts and molds. It also helps in slowing down the action of enzymes because it removes moisture. People have 
been preserving food through drying for thousands of years, because dried food yields maximum quantity for the least volume $[6,7]$

\section{MATERIALS AND METHODS}

Processing Procedures of Locust Bean Fruits

The fermented locust bean was processed following the procedure presented on the flow chart in Figure 1.

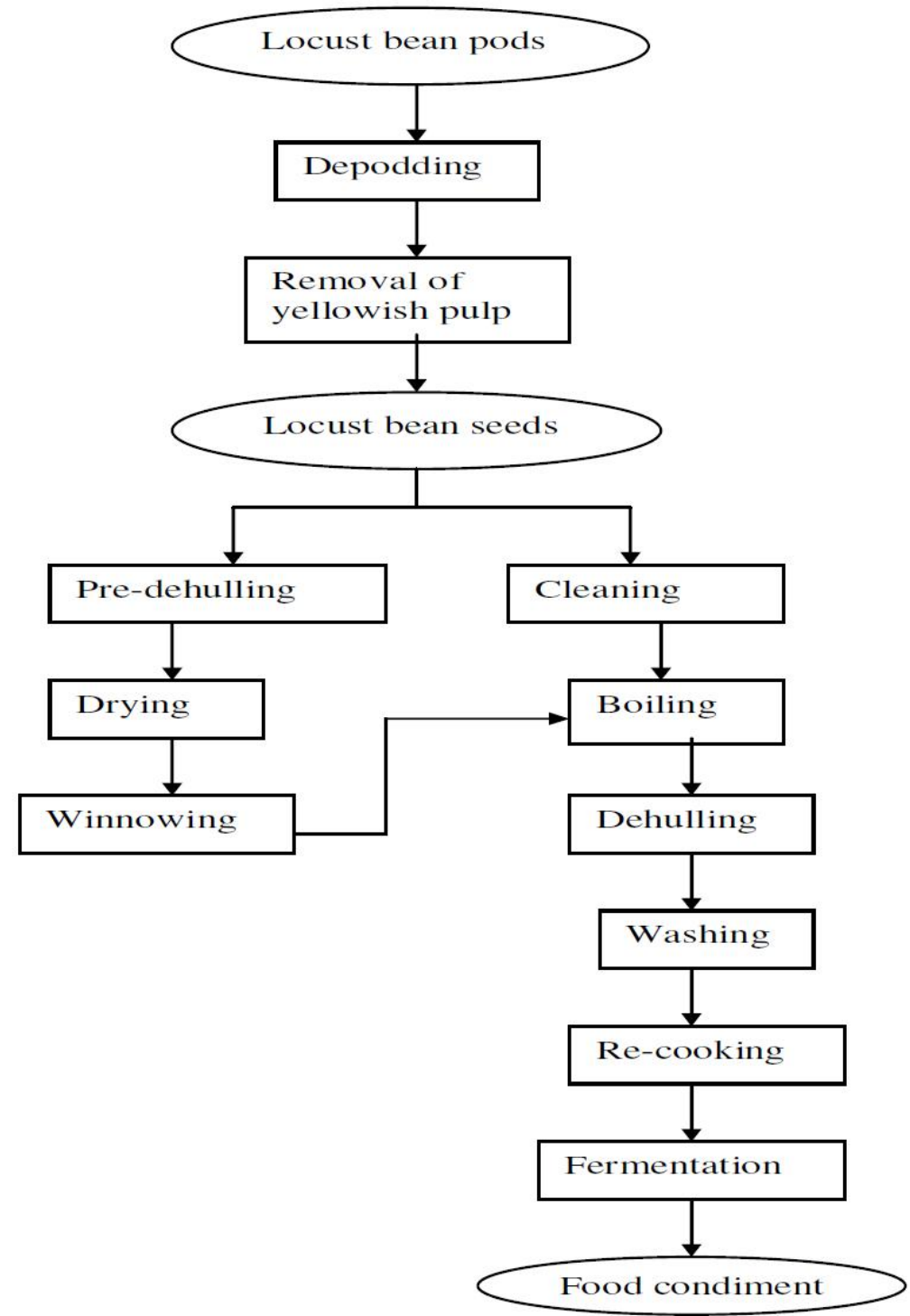

Fig.1: Flow chart for traditional processing of locust bean fruits to food condiment [9]

\section{Types of experimental dryer}

Two different experimental dryers were used, they are, indirect solar dryer and mechanical cabinet dryer Drying with mechanical dryer

$100 \mathrm{~g}$ of fermented locust beans sample was placed in a perforated tray of the cabinet dryer as shown in plate 3.3. The samples were subjected to drying at $45^{\circ} \mathrm{C}, 55^{\circ} \mathrm{C}, 65^{\circ} \mathrm{C}$ and $75^{\circ} \mathrm{C}$ at air velocity rate at $0.9 \mathrm{~m} / \mathrm{s}$. And the weight loss were measured at an interval of 30 mins until there is no further reduction in weight, the moisture content of the sample was determined by an oven dry method.

\section{Open sun drying}

$100 \mathrm{~g}$ of fermented locust beans was loaded in a net and was placed inside a tray. The initial weight of the condiment was noted and the subsequent weights were taken at the intervals of 30 mins. A sensitive weighing balance was used for the weight measurement.

\section{Indirect solar drying}

$100 \mathrm{~g}$ of fermented locust beans was placed inside the tray that is inside the solar dryer. The initial weight of the sample was taken and subsequent ones were taken at intervals of 30mins. A sensitive weighing balance was used for weight measurement and the temperature 
regulator was used to determine the temperature inside the dryer.

\section{Temperature measurement}

The dry air and ambient temperature were taken using a thermometer and were recorded in the data book.

\section{Determination of initial moisture content}

$10 \mathrm{~g}$ of the sample was weighed into a previously weighed crucible. The crucible plus sample taken was transferred into the oven set at $102^{\circ} \mathrm{C}$ to dry for 24 hour, the crucible plus the sample was removed from the oven and transferred to desiccators, cooled for ten minutes and weighed. The moisture content was calculated as percentage moisture (AOAC 2005)

\section{Proximate Composition}

The crude protein content, crude ash, crude fat, crude fibre and carbohydrate content of the samples were determined using standard methods as reported by [10].

\section{RESULTS AND DISCUSSION}

Moisture content of the locust beans

The average initial moisture content of the fresh fermented locust beans was $61.1 \%$ (wb). This value agreed well with reports from literature [11].

\section{Weather Condition}

During this experiment, the weather condition was slightly favorable for both the indirect solar drying and the sun drying. The solar radiation energy is maximum at midday and minimum at evening in the days of experiment. During the experiment, the ambient temperature ranged from $20-38^{\circ} \mathrm{C}$.

\section{Performance of the Drying Methods}

Table 1 shows the drying time, final moisture content and the weight of water in the sample after drying for all the drying methods. The mechanical dryer at air temperature of $75^{\circ} \mathrm{C}$ gave the least drying time. This indicates that, it takes a lesser time to dry at higher temperature.

Table.1: The drying time and moisture content at sun, solar and air temperature of 45, 55, 65 and $75^{\circ} \mathrm{c}$ at air velocity of

$0.9 \mathrm{~m} / \mathrm{s}$.

\begin{tabular}{lllll}
\hline $\begin{array}{l}\text { Drying } \\
\text { Methods }\end{array}$ & $\begin{array}{l}\text { Fresh locust } \\
\text { beans }(\text { g) }\end{array}$ & $\begin{array}{l}\text { Weight of water } \\
\text { after drying (g) }\end{array}$ & $\begin{array}{l}\text { Final molsture } \\
\text { content }\end{array}$ & $\begin{array}{l}\text { Drying time } \\
\text { (hour) }\end{array}$ \\
\hline SUN & 100.30 & 5.71 & 12.76 & 23 \\
SOLAR & 100.09 & 6.56 & 14.38 & 23 \\
MEC $45^{\circ} \mathrm{C}$ & 100.00 & 6.90 & 14.74 & 17 \\
MEC $55^{\circ} \mathrm{C}$ & 100.39 & 7.01 & 15.34 & 15 \\
MEC $65^{\circ} \mathrm{C}$ & 100.39 & 6.88 & 15.09 & 13 \\
MEC $75^{\circ} \mathrm{C}$ & 100.47 & 5.78 & 13.02 & 6 \\
\hline
\end{tabular}

\section{The indirect solar dryer}

The maximum temperature obtained for the indirect solar dryer was $48^{\circ} \mathrm{C}$ and it took 23 hours to reach a final moisture content of $14.38 \%$ (dry basis $(\mathrm{db})$ ).

\section{Mechanical drying characteristics of fermented locust} beans

The plot of the drying characteristics curve of fermented locust beans is shown in Figures 1 to 3 . The moisture content was 14.74, 15.34, 15.09 and $13.02 \%$ at air temperature of $45,55,65$ and $75^{\circ} \mathrm{C}$ respectively after the drying process. Figure 4.1 shows that the moisture content reduces with drying time. The mechanical dryer at air temperature of $75^{\circ} \mathrm{C}$ gave the least drying time while air temperature of $45^{\circ} \mathrm{C}$ gave the highest drying time. Figure 4.2 also shows that the higher the drying air temperature, the faster the drying process. The falling rate follows after the constant rate for all the samples at air velocity of $0.9 \mathrm{~m} / \mathrm{s}$. The constant-rate period occurred in a very short time in comparison with the whole drying time.
Figure 2 and 3 show that the drying rate reduces with increasing drying time. The highest drying rate was observed during the early hour for all the drying air temperatures. The final drying rates are $0.18,0.02,0.3$ and $0.03 \mathrm{~kg} / \mathrm{hr}$ for drying air temperature of 45, 55, 65 and $75^{\circ} \mathrm{C}$ respectively. However, the peak drying rate was observed at air temperature of $75^{\circ} \mathrm{C}$.As moisture is further removed, the falling rate curve is observed.

As the moisture reduces, more energy is needed to remove the inner moisture which gives rise to the falling rate. Since the energy supplied for drying is constant, there was a reduction in the drying rate. The initial drying rate was high because moisture for evaporation came from regions near the surface. As drying continues, the drying rate gradually decreased because water to be evaporated must be transported from the inner layers to the surface of the material. Therefore, the falling rate region expressed a resistance to heat and mass transfer inside the material [12]. This result is similar to the observations on the drying of garlic slice [13] and onions slices [14] 


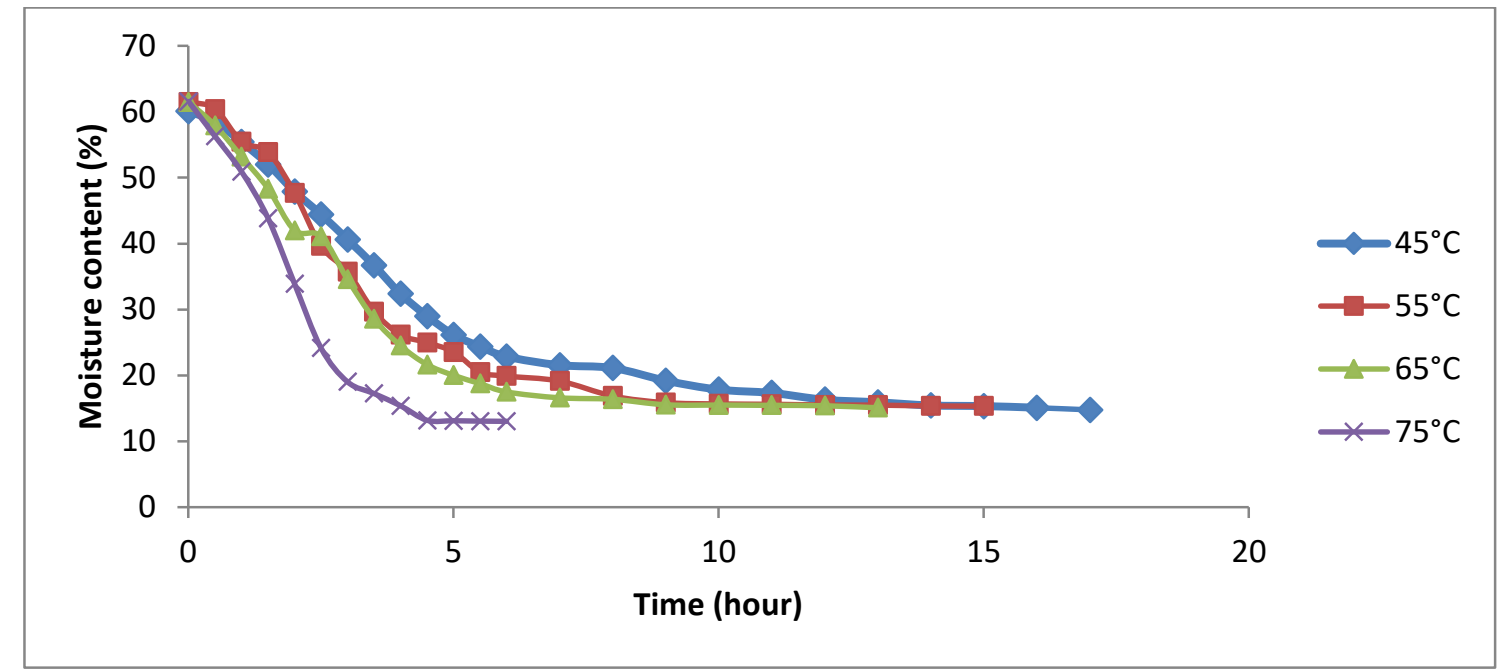

Fig.1: Variation of moisture content with drying time for mechanically dried fermented locust beans.

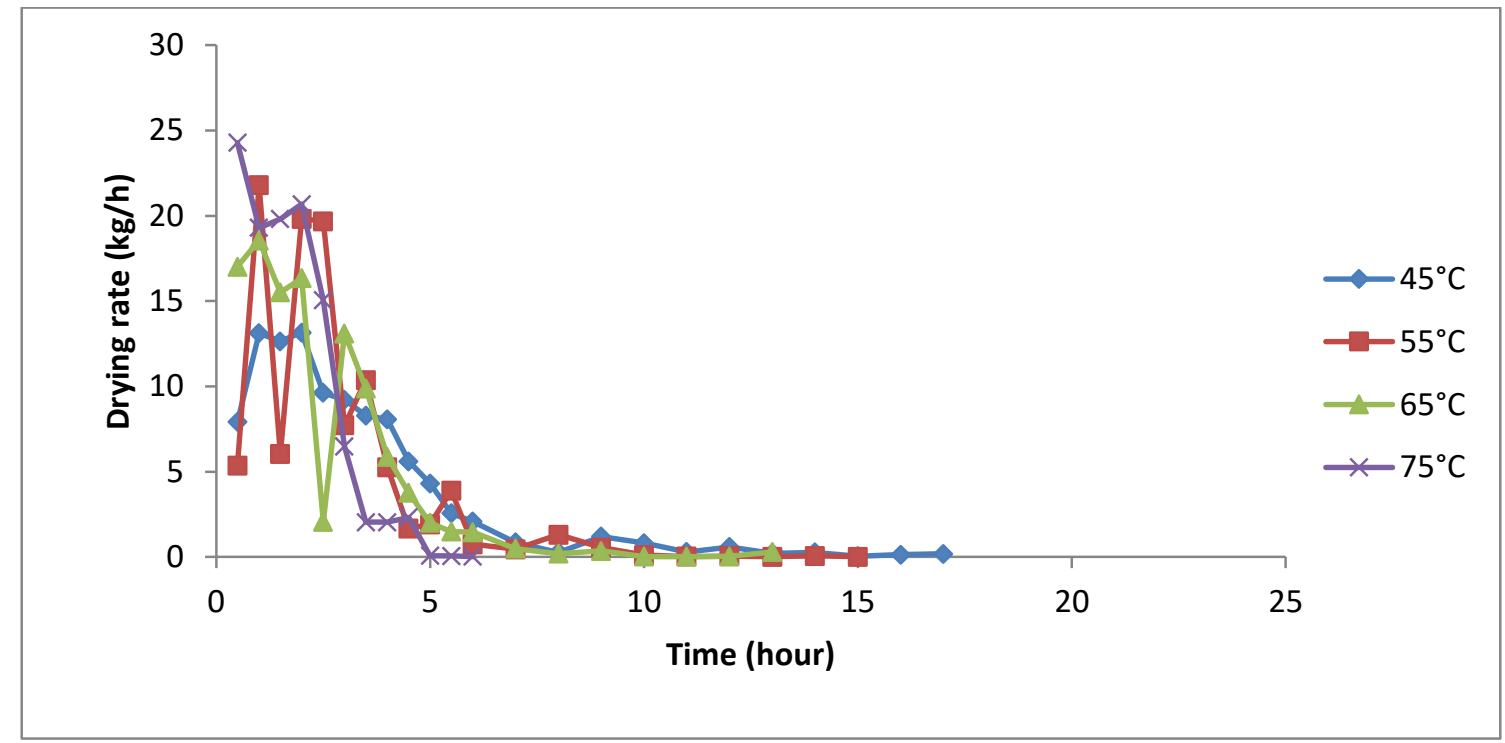

Fig.2: Variation of drying rate with drying timefor mechanically dried fermented locust beans.

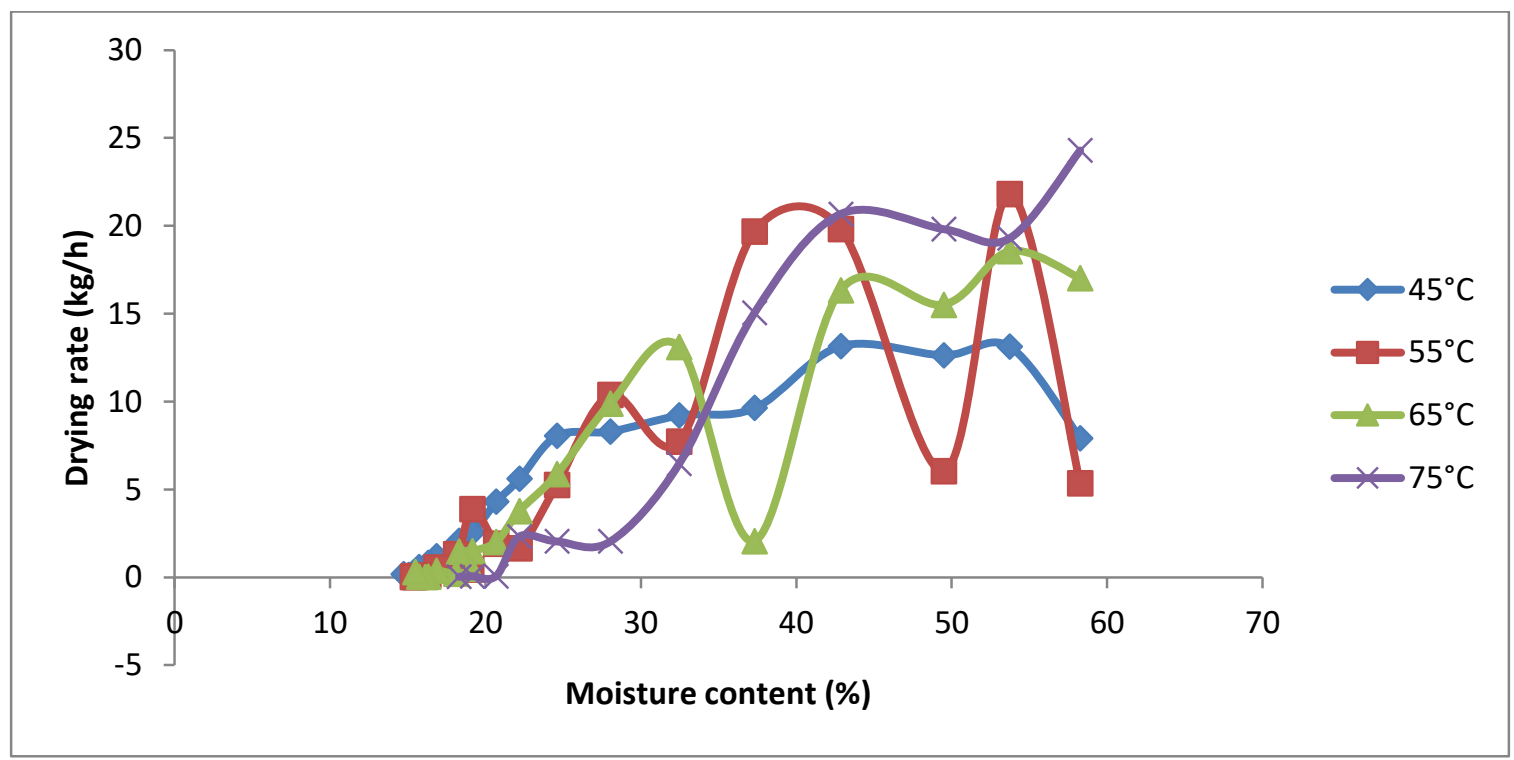

Fig.3: Variation of drying rate with moisture content for mechanically dried fermented locust beans. 


\section{Solar drying characteristics of fermented locust beans}

The plot of the drying characteristics curve for solar drying is shown in Figures 4 to 6 . The moisture content curve against time is shown in figure 4 . It shows a reduction in moisture content of the wet fermented locust beans with time.

There was fluctuation in the drying rate against time as shown in figure 5. This may be due to the rise and fall of the solar radiation due to the weather condition. The drying process occurred mainly at the falling-rate drying period because there was almost no constant-rate drying period. This indicates that the mode of mass transfer in the material was a moisture diffusion process [15]. It was also noted that after undergoing a short heating period, the drying rate significantly increased. Moisture for evaporation has to come from the regions near the surface. As drying continues, the drying rate decreases as water to be evaporated must be transported from inner layers of the material to the surface layer. Therefore, the falling rate region expressed a significant increase in resistance to heat and mass transfer inside the material [12]. The drying rate observed in this research was similar to the results reported on the thin layer solar drying process of grapes [16] and apricots $[17,18]$.

\section{Sun drying characteristics of fermented locust beans}

The plot of the drying characteristics curve for sun drying is shown in Figures 7 to 9. The moisture content curve against time is shown in Figure 7 . The curve shows a reduction in moisture with time.
There was fluctuation in the drying rate against time. This may be due to the rise and fall of solar radiation due to the weather condition. The drying process also occurred at the falling-rate drying period because there was almost no constant-rate drying period. During the drying process, water is removed from the wet fermented locust beans to the environment along time, till equilibrium is reached. According to several authors, air drying of food always have a short or no constant rate period, followed by a long falling-rate period This may be to the fact that most foods are dense solids with low porosity, and so molecular diffusion of the liquid through the product is limited.Moreover, the continuous evaporation of surface moisture could lead to formation of a hard surface layer which reduces the moisture removal from the material, thus reducing the drying rate $[19,20$, $21,22]$.

The drying rates were higher at the beginning of the drying process and later decreased with decreasing moisture content. [23] had similar occurrence in the study of the drying kinetics of open sun drying of fish. As indicated in the curves of Fig. 6, the drying occurred mainly under falling rate of drying period. During the falling rate period, the predominant mechanism of mass transfer in the sample is that of internal mass transfer. This result also agree with the study of thin layer drying of olive fruit [24].

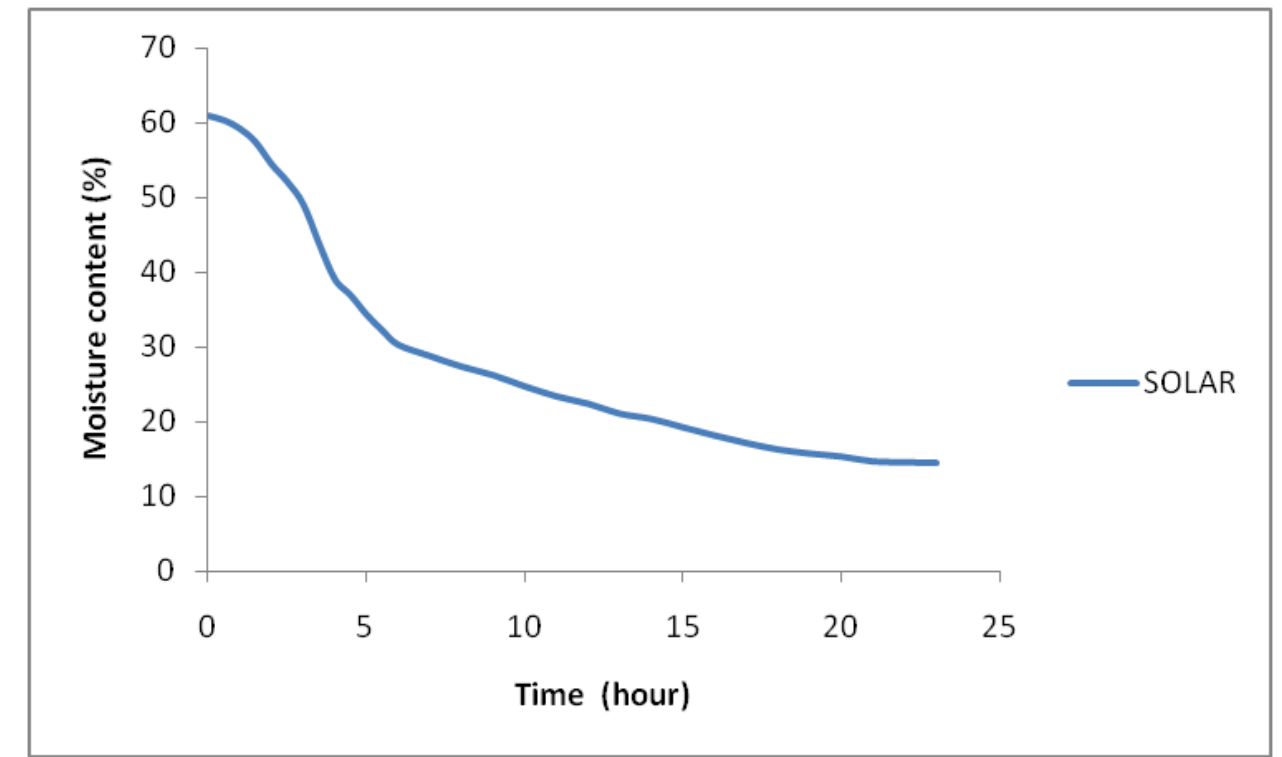

Fig.4: Variation of moisture content with drying time for solar dried fermented locust beans. 


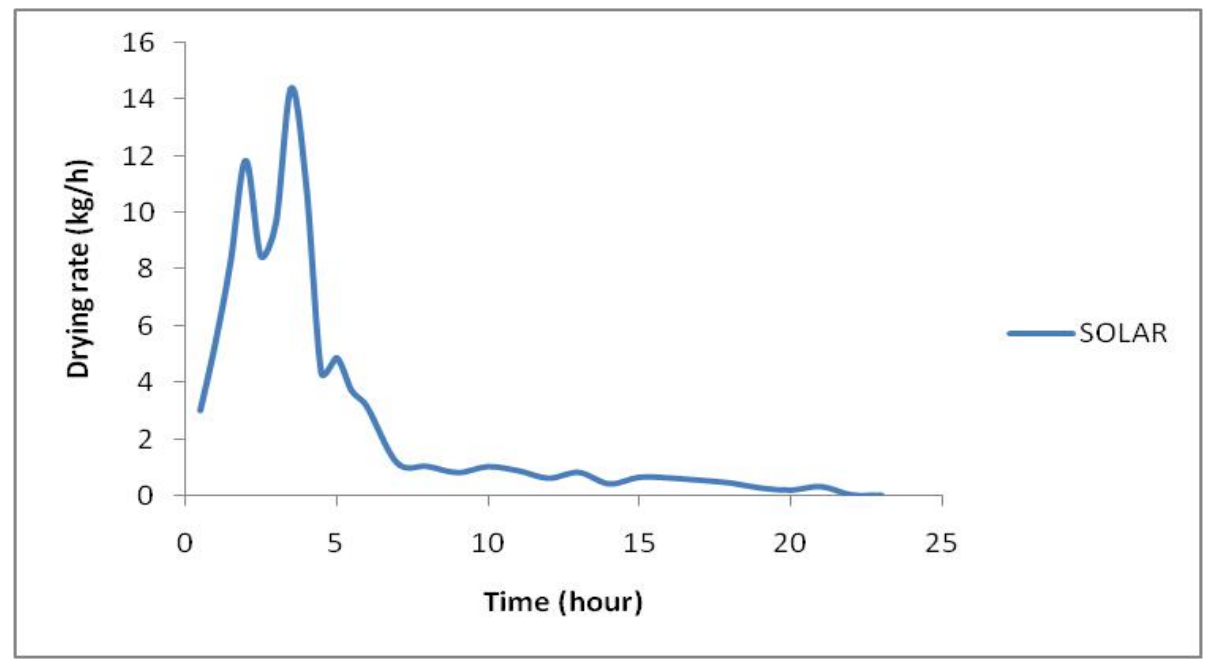

Fig.5: Variation of drying rate with drying time for solar dried fermented locust beans.

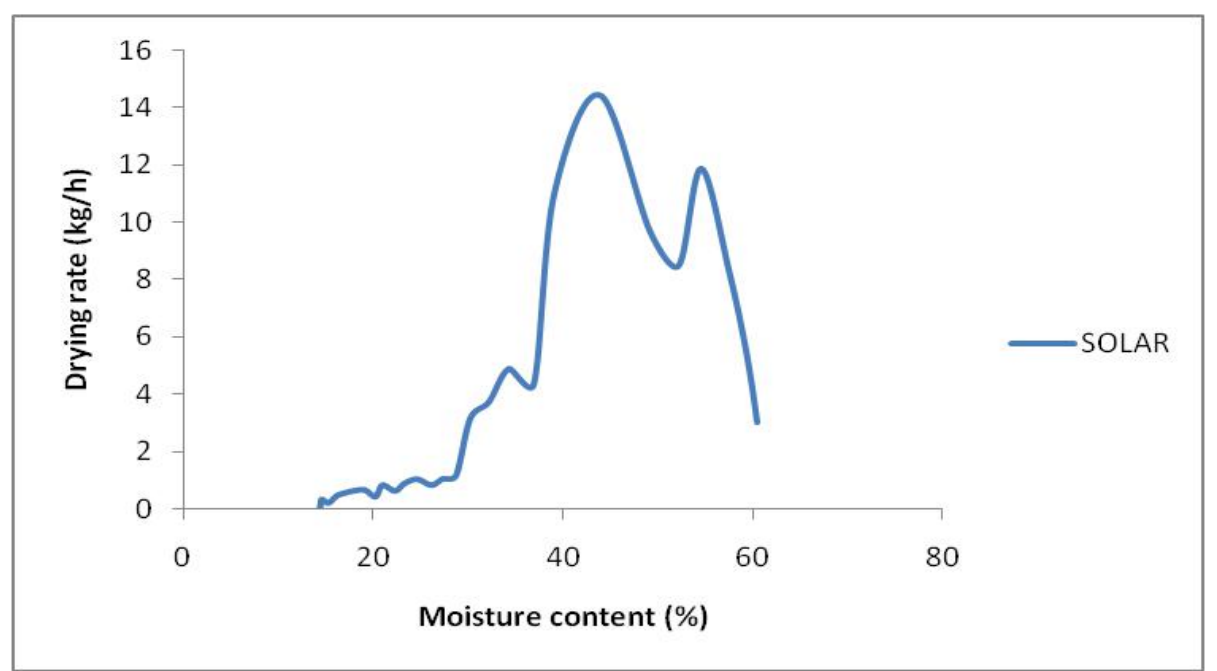

Fig.6: Variation of drying rate with moisture content for solar dried fermented locust beans.

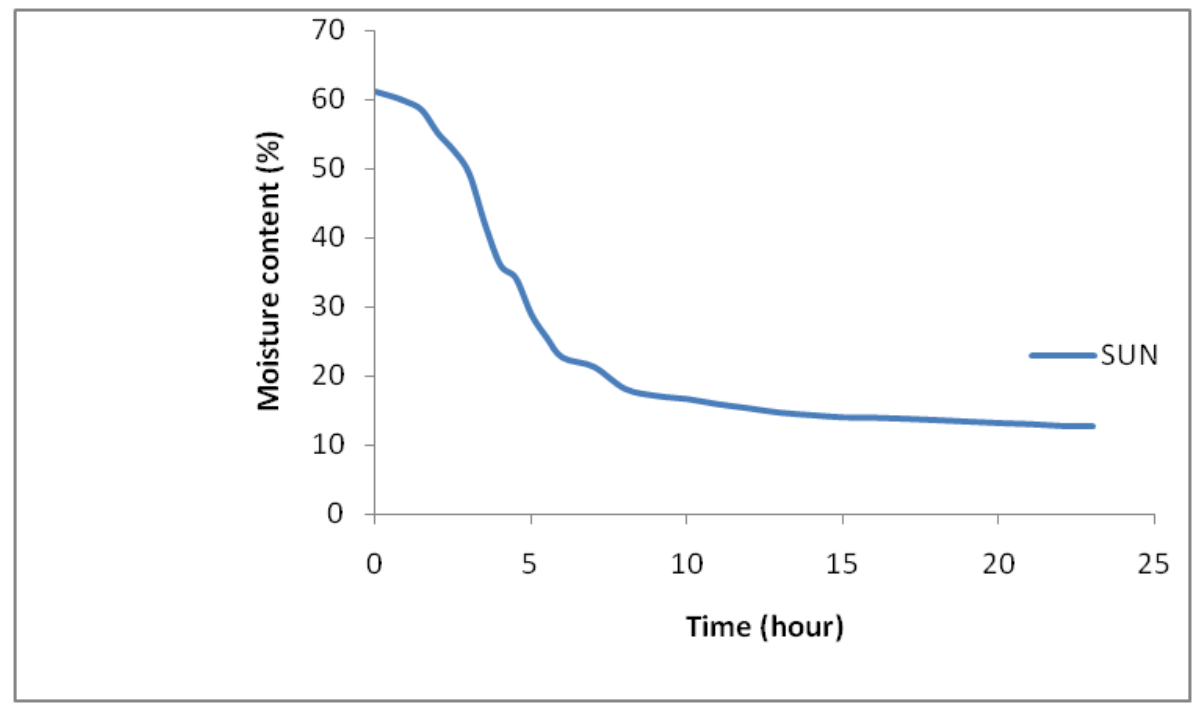

Fig.7: Variation of moisture content with drying time for sun dried fermented locust beans. 


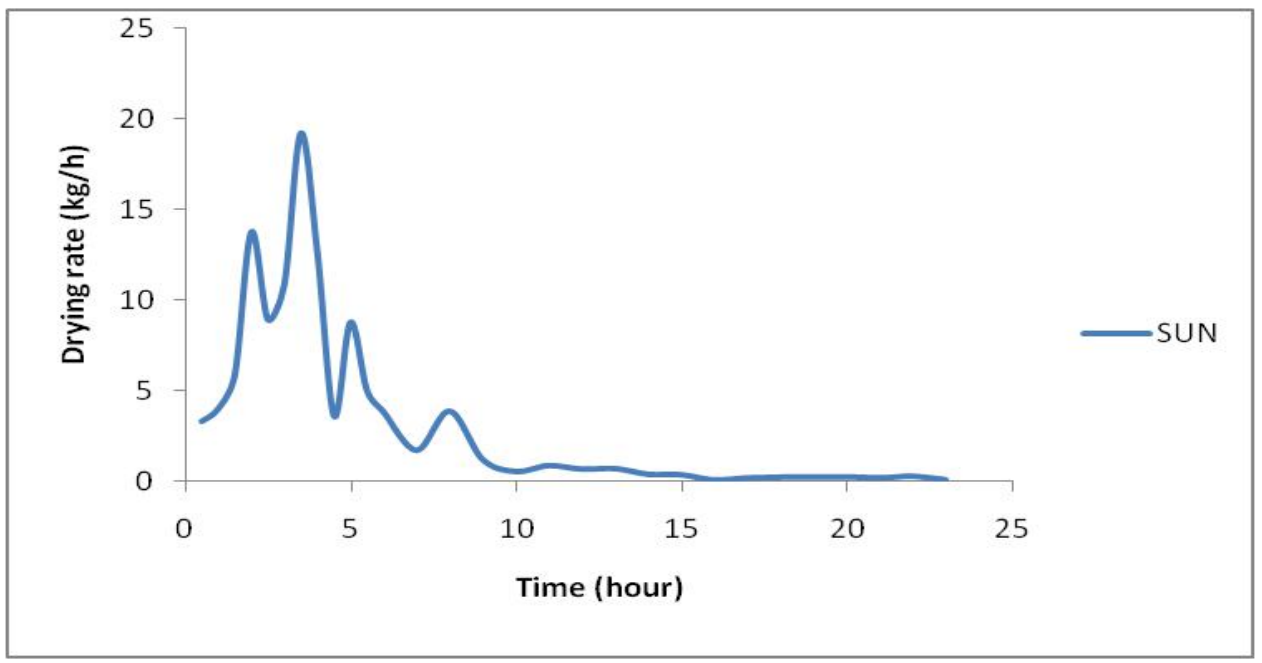

Fig.8: Variation of drying rate with drying time for sun dried fermented locust beans.

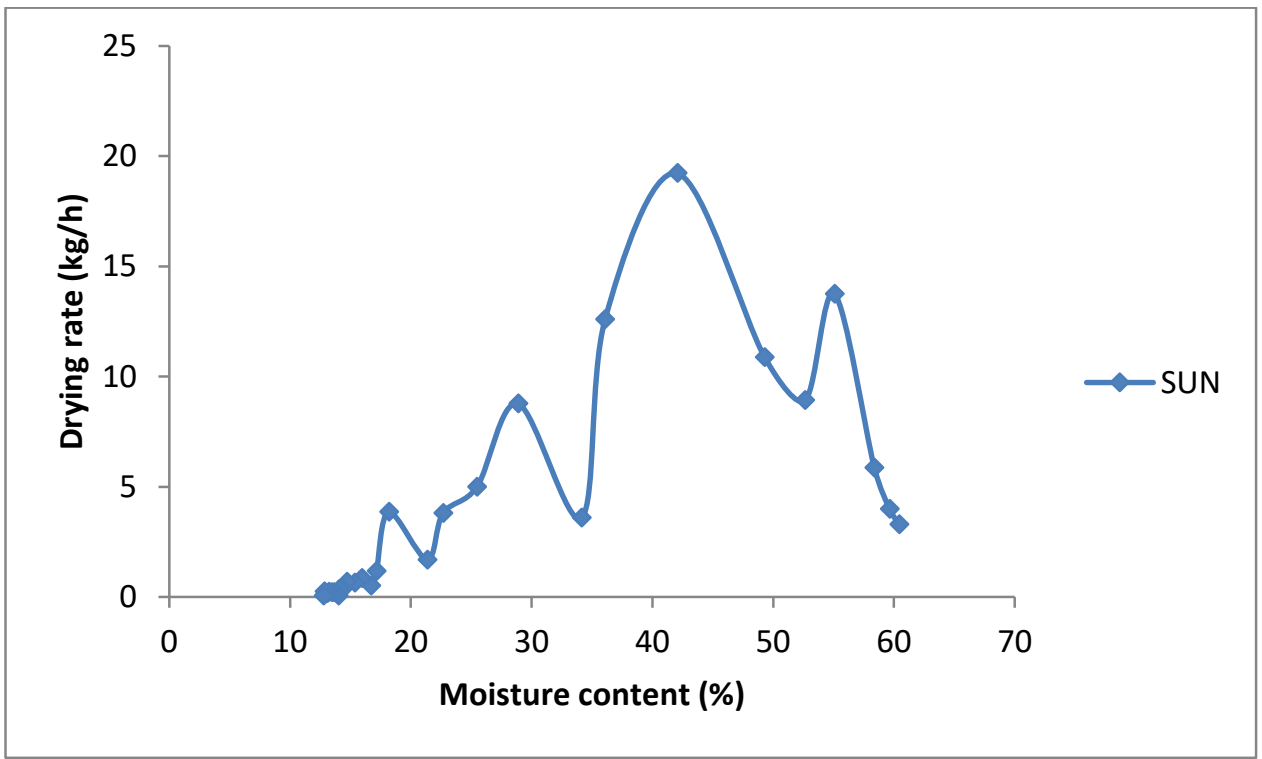

Fig.9: Variation of drying rate with moisture content for sun dried fermented locust beans.

\section{NUTRITIONAL QUALITY OF DRIED FERMENTED LOCUST BEANS}

Quality of mechanically dried fermented locust beans

Table 2 shows the result obtained from the proximate analysis of the wet and dried fermented locust beans. The moisture content of the dried fermented locust beans are 14.71, 15.30, 15.09 and $13.00 \%$ at 45, 55, 65 and $75^{\circ} \mathrm{C}$ respectively. The results showed that there were significant $(\mathrm{P}<0.05)$ differences between moisture content of the wet fermented locust beans and the dried ones. The result shows the ash content of the samples ranges from 2.68 to $2.95 \%$.Differences in ash may be due to variation in drying air temperature. The carbohydrate content of the samples increased from 24.08 to $43.65 \%$. The result agreed with the result of the proximate composition of fermented locust beans reported by [25]. The variation may be due to differences in air temperature. It was reported that African locust beans is rich in plant protein and essential fatty acids [26]. The results showed that there were significant $(\mathrm{P}<0.05)$ differences between the crude protein of the wet fermented locust beans and the dried ones. The condiment at air temperature of $55^{\circ} \mathrm{C}$ has the highest crude protein content of $27.81 \%$ and crude fat of $27.4 \%$ The difference in the levels of protein content obtained in this study may be attributed to differences in air temperature. [27] reported that crude protein contents of $29.00 \%, 32.00 \%$ and $37.34 \%$ were obtained for the raw, boiled and fermented locust beans respectively. The decrease in protein of the dried fermented locust beans may be due to the absence of proteolytic enzyme which is present in the wet fermented locust beans as reported by [28] There was a significant reduction in the proximate 
composition of all the mechanical air temperature dried samples compared to the wet fermented locust beans.

\section{Quality of solar dried fermented locust beans}

The proximate composition of the solar dried fermented locust beans is shown in Table 3. The following data were obtained, \% moisture (14.33), \% protein (26.44), $\%$ fat (27.55), \% carbohydrate (38.38), \% fibre (4.48) and $\%$ ash content (2.81). This data showed that, the solar drying has effect on the nutritional composition of the fermented locust beans. The nutritional composition of the beans was reduced due to the solar drying process. There was a significant reduction of the proximate composition of the dried locust beans compared to the wet fermented locust beans. [29] Reported a decrease in the nutritional composition in the solar drying of fresh amaranthus (tete), vernonia (ewuro) and fluted pumpkin (ugu).

Quality of sun dried fermented locust beans

The proximate composition of the sun dried fermented locust beans is shown in Table 3. The following data's were obtained, \% moisture (12.78), \% protein (25.75), \% fat (27.41), \% carbohydrate (39.82), \% fibre (4.11) and $\%$ ash content (2.80). The condiment at the sun drying gave the least protein content. The proximate composition of the sun dried fermented locust beans showed that, the sun drying has effect on the nutritional composition of the fermented locust beans. There was a significant reduction in the proximate composition compared to the wet fermented locust beans. Similar report was given by [30] in the sun drying of fish.

Table.2: Nutritional value and physical characteristics of mechanically dried fermented locust beans

\begin{tabular}{|c|c|c|c|c|c|c|c|}
\hline Samples & $\% \mathrm{MC}$ & $\%$ ASH & $\%$ Crude Fat & $\begin{array}{l}\% \text { Crude } \\
\text { Protein }\end{array}$ & $\% \mathrm{CHO}$ & $\begin{array}{l}\text { \%Crude } \\
\text { Fibre }\end{array}$ & Aroma \\
\hline Fresh & $55.22 \pm 0.02^{\mathrm{e}}$ & $3.37 \pm 0.02^{\mathrm{d}}$ & $35.19 \pm 0.02^{\mathrm{d}}$ & $\begin{array}{l}32.07 \pm \\
0.02^{\mathrm{e}}\end{array}$ & $\begin{array}{l}24.08 \pm \\
0.02^{\mathrm{a}}\end{array}$ & $\begin{array}{l}5.18 \pm \\
0.02^{\mathrm{d}}\end{array}$ & $\begin{array}{l}\text { Very } \\
\text { Pronounced }\end{array}$ \\
\hline MECH 45 & $14.71 \pm 0.04^{\mathrm{b}}$ & $2.68 \pm 0.03^{\mathrm{a}}$ & $27.39 \pm 0.09^{c}$ & $\begin{array}{l}27.61 \pm \\
0.07^{\mathrm{c}} \\
27.81 \pm\end{array}$ & $\begin{array}{l}39.03 \pm \\
0.06^{\mathrm{c}} \\
38.51 \pm\end{array}$ & $\begin{array}{l}3.03 \pm \\
0.03^{\mathrm{c}} \\
3.29 \pm\end{array}$ & $\begin{array}{l}\text { Moderately } \\
\text { Pronounced } \\
\text { Very }\end{array}$ \\
\hline MECH 55 & $15.30 \pm 0.07^{\mathrm{d}}$ & $2.73 \pm 0.06^{\mathrm{a}}$ & $27.4 \pm 0.35^{\mathrm{c}}$ & $0.01^{\mathrm{d}}$ & $0.01^{\mathrm{b}}$ & $0.01^{\mathrm{c}}$ & Pronounced \\
\hline MECH 65 & $15.09 \pm 0.03^{c}$ & $2.82 \pm 0.01^{b}$ & $25.82 \pm 0.06^{\mathrm{b}}$ & $\begin{array}{l}27.53 \pm \\
0.02^{\mathrm{b}}\end{array}$ & $\begin{array}{l}40.35 \pm \\
0.03^{\mathrm{d}}\end{array}$ & $\begin{array}{l}33.33 \pm \\
0.29^{\mathrm{b}}\end{array}$ & Pronounced \\
\hline MECH 75 & $13.00 \pm 0.02^{\mathrm{a}}$ & $2.95 \pm 0.04^{\mathrm{c}}$ & $23.70 \pm 0.02^{\mathrm{a}}$ & $\begin{array}{l}27.04 \pm \\
0.03^{\mathrm{a}}\end{array}$ & $\begin{array}{l}43.65 \pm \\
0.02^{\mathrm{e}}\end{array}$ & $\begin{array}{l}3.56 \pm \\
0.01^{\mathrm{a}}\end{array}$ & $\begin{array}{l}\text { Slightly } \\
\text { Pronounced }\end{array}$ \\
\hline
\end{tabular}

Mean in each column bearing different letter are significantly different at 5\% level of probability

Table.3: Nutritional value and physical characteristics of sun and solar dried fermented locust beans

\begin{tabular}{|c|c|c|c|c|c|c|c|}
\hline \multirow[b]{2}{*}{ Samples } & \multirow[b]{2}{*}{$\% \mathrm{MC}$} & \multirow[b]{2}{*}{$\%$ ASH } & \multirow[b]{2}{*}{$\%$ Crude Fat } & \multicolumn{2}{|l|}{$\%$ Crude } & \multirow{2}{*}{$\begin{array}{l}\text { \%Crude } \\
\text { Fibre }\end{array}$} & \multirow[t]{2}{*}{ Aroma } \\
\hline & & & & Protein & $\% \mathrm{CHO}$ & & \\
\hline & & & & & & & Very \\
\hline FRESH & $55.22 \pm 0.02^{c}$ & $3.37 \pm 0.02^{\mathrm{c}}$ & $35.19 \pm 0.02^{c}$ & $32.07 \pm 0.02^{\mathrm{c}}$ & $24.08 \pm 0.02^{\mathrm{a}}$ & $5.18 \pm 0.02^{c}$ & Pronounced \\
\hline SUN & $12.78 \pm 0.10^{\mathrm{a}}$ & $2.80 \pm 0.01^{\mathrm{a}}$ & $27.41 \pm 0.02^{\mathrm{a}}$ & $25.75 \pm 0.03^{\mathrm{a}}$ & $39.82 \pm 0.05^{\mathrm{c}}$ & $4.11 \pm 0.02^{\mathrm{a}}$ & Pronounced \\
\hline SOLAR & $14.33 \pm 0.05^{\mathrm{b}}$ & $2.81 \pm 0.02^{\mathrm{b}}$ & $27.55 \pm 0.04^{b}$ & $26.44 \pm 0.07^{b}$ & $38.38 \pm 0.11^{\mathrm{b}}$ & $4.48 \pm 0.10^{\mathrm{b}}$ & Pronounced \\
\hline
\end{tabular}

Mean in each column bearing different letter are significantly different at $5 \%$ level of probability

\section{CONCLUSION}

The drying process of the fermented locust beans for air temperature of $75^{\circ} \mathrm{C}$ was the shortest being the highest air temperature. The moisture content and the drying rate decreases with the drying time for all the drying methods. The drying method has a significant effect on the proximate composition and the organoleptic properties of the fermented locust beans. To have maximal nutritional values from fermented locust beans, it is best to consume it fresh. However, for storage purposes, the mechanical drying method with drying temperature of $55^{\circ} \mathrm{C}$ at air velocity of $0.9 \mathrm{~m} / \mathrm{s}$ gave the best quality condiment.

\section{REFERENCES}

[1] Aju, P.C., Iwuanyanwu, U.P., Popoola, L.A. and Uwalaka, R.E. 2008. An assessment of nutrition and commercial values of Gnetum africana in Imo state, Nigeria. In: J.C. Onyekwelu Adekunle and D.O. Oke (Ed) Proceedings of the First National Conference of the Forest and Forestry Products Society. 16th-18th April, At the Federal University of Technology, Akure. pp. 18-22. 
[2] Oduro, I., Ellis, W.O. and Narh, S.T. 2007. Expanding breadfruit Utilization and its potentials for Pasta Production. Discovery and Innovation. 19: 243-247.

[3] Popoola, L. and Galaudu, M.S. 2000. Prioritization of indigenous spice-species for agroforestry in the semi-arid zone of Nigeria. Bioprospector. 2: 103-116.

[4] Beaumont, M. 2002. Flavoring composition prepared by fermentation with bacillus spices. Int. J. Microbiol. 75: 189-196.

[5] Oladele, F.A., Fawole, M.O. and Bhat, R.B. 1995. Leaf anatomy of Parkia clappertonaire Keay (Mimosaceae). Korean J. Biol. 28: 21-28.

[6] Klanjcar, J., M. Kopac, D. Kosem, and K. Kozlovic. 2002. Dawadawa. www.bf.uni-lj.si/zt/biotech/seminarabsract/zivil/

[7] Amoa-Awu, W.F., M. Owusu and P. Feglo, 2005. Utilization of unfermented cassava flour for the production for indigenous African fermented Food, Agbelina. World. J. Microbial. Biotechnol., 21: 1201-1207.

[8] Omosebi, M.O. and Otunola, E.T. (2013) Preliminary studies on tempeh flour produced from different Rhizopus species. Int. J. Biotechnol. Food Sci. 1(5): 90-96

[9] Akande, F.B., Adejumo, O.A., Adamade, C.A. and Bodunde, J. (2010): Processing of Locust Bean Fruits: Challenges and Prospects. African Journal of Agricultural Research Vol. 5 (17): 2268- 2271.

[10] AOAC, 2000. Association of Official Analytical Chemists. Official Method of Analysis. 17th Edn., Gaithersburg, USA.

[11] Alabi, D.A., Akinsulire, O.R. and Sanyanolu, M.A. 2005. Qualitative determination of chemical and nutritional composition of Parkia biglobosa (Jacq.) Benth. August. African J. Biotech. 4 (8): 812-815.

[12] Kashaninejad, M, Mortazavi, A, Safekordi, A and LG Tabil, L. G. (2007). Thin layer drying characteristics and modeling of pistachio nuts. J. Food Eng; 78, 98-108.

[13] Madamba, P. S., Driscoll, R. H. and Buckle, K. A. (1996). The thin layer drying characteristics of garlic slices. Journal of Food Engineering 29: 75 - 97

[14] Sarsavadia, P. N., R. L. Sawhney, D. R. Pangavhane, and S. P.Singh. 1999. Drying behavior of brined onion slices. Journal of Food Engineering, 40: 219- 226.

[15] Menges, H.O. and C Ertekin, C.(2006): Thin layer drying model for treated and untreated Stanley plums. Energ. Convers. Manage. 47, 2337-48.

[16] Bala, B.K., Mondol, M.R.A., 2001, Experimental Investigation on Solar Drying of Fish Using Solar Tunnel Drier, Drying Technology, 19(2), pp. 1-10.

[17] Banout, J., Ehl, P., Havlik, J., Lojka, B., Polesny, Z., Verner, V., 2011, Design and performance evaluation of a Double-pass solar drier for drying of red chilli (Capsicum annum L.), Solar Energy, 85, pp. 506-515.

[18] Belessiotis, V and Delyannis, E. (2011). Solar Drying. Solar Energy, 85(8): 1665-1691

[19] Madamba, P.S. (2003). Thin layer drying models for osmotically pre-dried young coconut. Drying Technology, 21(9), 1759-1780.
[20] Mazza, G., \& Le Maguer, M. (1980). Dehydration of onion: some theoretical and practical considerations. Journal of Food Technology, 15, 181-194.

[21] Mulet, A. (1994). Drying modelling and water diffusivity in carrots and potatoes. Journal of Food Engineering, 22, 329348.

[22] Ratti, C. and Mujumdar, A. S. (1996). Drying of Fruits. Processing Fruits: Science and Technology, biology, Principles and Applications. L. P. Somogyi, H. S. Ramaswamy and Y. H. Hui. California, Technomic Publishing. Vol 1.

[23] Dilip Jain and Pankaj B. Pathare (2007), Drying kinetics of open sun drying of fish. Journal of Food Engineering 78, 1315-1319

[24] Belgacem Mahdhaoui, Ridha Fethi Mechlouch1, Ammar Mahjoubi, Karim Zahafi, and Ammar Ben Brahim1 (2013). Mathematical model on thin layer drying of of olive fruit (Olea europeae L.). Journal of Agricultural Technology, Vol. 9(5): 1097-1110

[25] Oladunmoye, M.K., 2007. Effect of fermentation onnutrient enrichment of locust beans (Parkia biglobosa). Res. J. Microbiol., 2: 185-189.

[26] Antai, S.P. and Ibrahim, 1986. Microorganisms associated with Africa locust beans (Parkia filicoidea Welw) fermentation for 'dawadawa' production. Applied Bacteriol., 61: 145-148.

[27] Omafunbe, B.O., O.S. Falade, B.A. Osuntogun and S.R.A. Adewusi, 2004. Chemical and biochemical change in African locust beans (Parkia biglobosa) and melon (Citrullus vulgaris) seeds during fermentation to condiments. Pak. J. Nutr., 3: 140-145.

[28] Oyewole, O.B. and S.A. Odunfa, 1990. Effect of cooking method on water absorption and ease of dehulling in preparation of African locust beans for iru. Int. J. Food Sci. Tec., 25: 461-463.

[29] Awogbemi, Omojola and Ogunleye, I. Olusola. (2009). Effects of drying on the qualities of some selected Vegetables. International Journal of Engineering and Technology. Vol.1, No.51793-8236

[30] Ojutiku RO, Kolo RJ, Mhammed ML (2009). Comparative study of sun drying and solar tent drying of Hyperopisus bebeoccidentalis. Pak. J. Nutr. 8(7):955-957. 